\title{
The Development of Pop Up 3D General Map Using Discovery Learning Models to Improve Creativity and Learning Outcomes of Social Studies Grade V Elementary School
}

\author{
Wahyu Kurnia Ningsih ${ }^{1, a,{ }^{*}}$, Yatim Riyanto ${ }^{1, b}$, Totok Suyanto $^{1, c}$ \\ 1Postgraduate of Basic Education, Surabaya State University, East Java, 60213, Indonesia \\ JI. Rektorat Unesa, Lidah Wetan Kecamatan Lakarsantri Surabaya, East Java, 60213, Indonesia \\ Email: a *wahyu.17079855056@mhs.unesa.ac.id; b jatimriyanto@gmail.com; c totoksuyanto@unesa.ac.id \\ Whatsapp Number $\{087751133371\}$
}

How to Cite : Ningsih, W., K., Riyanto, Y., \& Suyanto, T. (2019). The Development of Pop Up 3D General Map Using Discovery Learning Models to Improve Creativity and Learning Outcomes of Social Studies Grade V Elementary School. International Journal for Educational and Vocational Studies, 1 (2), 86-91.

\section{ARTICLE HISTORY}

Received: 17 May 2019

Revised: 25 May2019

Accepted: 23 May 2019

\section{KEYWORDS}

Pop Up 3D General Maps;

Discovery Learning Models;

Creativity;

Learning Outcomes;

Social Studies;

\begin{abstract}
The researcher was interested in developing learning media "3D Pop Up general map". This study aims to develop a 3D Pop Up general map media and describe the feasibility and effectiveness of improving the creativity and learning outcomes of social studies material in the Indonesian geographical characteristics of grade V elementary school. This research was conducted in Ujung IX/ 34 SDN, Semampir, Surabaya in the second semester of the 2018-2019 academic year. The development of learning media in this study uses a 4-D model. In this study used instruments in the form of validation sheets, student activity observation sheets during learning, teacher and student response questionnaires to the media, student learning creativity observation sheets, and learning outcomes tests, affective and psychomotor observation sheets. The results of the study show: (1) the learning media developed meet the criteria: (a) the validity shown through the validator's assessment of the learning media is very good; (b) feasibility is shown through teacher and student responses to positive media questionnaires; (c) effectiveness, indicated by student activities in learning in the ideal time span, observations of student learning creativity when learning increases, completeness of cognitive, affective and psychomotor learning outcomes also increases. Thus the "3D Pop Up general map" can be used as an alternative to social studies learning in the fifth grade of elementary school.
\end{abstract}

This is an open access article under the CC-BY-SA license.

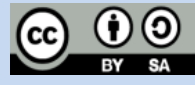

\section{INTRODUCTION}

Changes are part of an exchange, increase or decrease in value of a thing. According to Tilaar (2012, p.32) there are three major changes in power that change human life today, namely: first, democracy; second, the progress of science and technology; and third, globalization. One of the efforts to change is by revising the education curriculum in Indonesia.

In the 2013 revised edition of Curriculum, it was more oriented towards strengthening the character of students who had been strengthened by Presidential Regulation Number 87 of 2017 concerning Strengthening Character Education. This requires the teacher to be able to strengthen the character of the students by applying the main values of character that is religious, nationalist, independent, cooperative and good competence in learning activities. In addition to this, students must also be prepared to face global challenges, one of which is the indu- strial revolution 4.0. The availability of 21st Century skills can be a character enhancer for students, because it contains basic literacy competencies, critical thinking and problem solving, creativity and communication. Strengthening character education is the foundation of national education that strengthens the 2013 Curriculum.

One effort to familiarize and develop several competencies such as critical thinking, problem solving, creative and communication skills by involving students directly in solving contextual problems and poured in an idea in the form of creative representative work. In order to support this, we need a learning media that can inspire and activate students in the learning process. This is similar to the opinion of Asyhar (2011, p. 8) who concluded that "learning media are all things that are useful for sending messages from learning sources to recipients in a structured manner, so as to create a learning atmosphere 
that is conductive, effective and efficient."

Researchers tried to create 3D-based learning media with Pop Up drawing techniques, based on the opinions of these experts. The meaning of Pop Up pictures according to Rubin (2015, p.87) states that Pop Up means an imagination that when opened, paved, or lifted, will give rise to an impression with a three-dimensional appearance.

The choice of media is also associated with the level of cognitive development of students. The media is considered to have a match if applied to fifth grade elementary school students. This is based on the theory of Piaget (2010, p. 176) who states that at the age of 7-11 years, children are at the level of concrete operational thinking, which means children have the competence to think critically and logically.

Elementary school students in the 2013 Curriculum, the substance of the material on social studies subjects is suitable to be applied in 3D media with Pop Up techniques applied to the theme 9 Around Us which decomposes on the 2 Objects in Economic Activities and Subtem 3 Humans and Objects in the Environment. In the theme and sub-theme KD which contains the substance of social studies subjects namely KD 3.1 and KD 4.1 Based on this, the example of 3D Pop Up media that is considered appropriate is by making a general map that displays non-physical conditions (tribe, art, economic life, social, means of communication and transportation) and physical conditions in the form of geographical conditions (natural environment such as: mountains, oceans, lakes, beaches and plains). This media was chosen because the study sample had never used the Pop Up media which was modified by displaying a general map and cultural elements as its supporters in learning.

In the early stages of graphic media design in the form of front and back cover, blind maps of islands in Indonesia such as Sumatra, Java, Kalimantan, Papua, Sulawesi, Bali and Nusa Tenggara using the corel draw application, determine the size of the media which is then printed on ivory paper 310 grams in the form of a book, preparing the necessary images both in the form of $2 \mathrm{D}$ images and $3 \mathrm{D}$ images. 2D images are printed on sticker paper which includes natural features of mountains, highlands, lowlands, beaches, lakes and rivers, as well as images of airports and ports as modes of transportation. While 3D images made with the impression of Pop Up are printed using duplex paper and on the back are given steofofoam corks that have been glued together as a barrier to stand.

In addition to the media and subject matter chosen, to further optimize the learning outcomes and creativity of students, it is necessary to design learning according to syntax by using one of the learning models in the 2013 Curriculum. The intended learning model is Discovery Learning. According to Budiningsih (2005, p.43), "Discovery Learning Model is an effort to learn to understand concepts, meanings, and correlations through the process of discovery and search independently so that conclusions can be drawn." The existence of Pop Up based
3D general map learning media developed and applied using the Discovery Learning learning model also makes it the basis for solving problems in conventional and classical learning. The cognitive aspects that learners get not only in stage (C1), but to reach the stage (C5), which is able to create a creative work, as expressed by Bloom's on the taxonomy in Suyono (2011, p.169).

One of the foundations that also strengthens this research is the previous research entitled " Development Media of Pop Up Book in Event Value Nationalism Education Around Proklamasi to Enhance Critical Thinking of Grade V Elementary Students" by Aeni (2017) stating that "1) Media Pop Up Book is stated as valid and very useful for its feasibility as an enrichment book in clarifying the values of nationalism. 2) The use of Pop Up media is very helpful for students in clarifying the values of nationalism. 3) There is an increase in critical thinking of students using Pop Up media. "

This study aims to find out: 1) the process of developing the media; 2) media feasibility; 3) the effectiveness of the 3D general map media with the Discovery Learning model in improving the creativity and learning outcomes of social studies material in the geographical characteristics of Indonesian elementary school students.

The theoretical contribute provided in this study include: 1) providing information in the form of a process of finding answers to questions scientifically; 2) explore in-depth understanding of the substance of research which includes the content of social studies learning in the material geographical characteristics of Indonesia. While the practical contribute include: 1) for researchers it is useful to increase understanding of practice (professional development) by expert teams and to improve the situation where practice is implemented; 2) for other researchers it can be useful as a source of inspiration for compiling research; 3) for schools it can be useful to inspire educators to overcome problems in teaching and as an effort to improve the quality of learning in schools; 4) for educators to be inspired to carry out learning by using innovative learning models and media in delivering material and giving their assignments. So that it can activate students and improve their learning outcomes.

\section{METHODS}

The approach of this research is quantitative research. Research using quantitative methods is research that focuses on the use of variables and the relationship between variables one with other variables Riyanto (2007, p.152). Quantitative methods focus on using numbers with random sampling and data processed with statistics that aim to test hypotheses.

This research is included in the type of research and development (R \& D) which aims to develop learning media. Learning media developed in this study are Pop Up based 3D general map media on IPS material characteristic of geographical conditions. According to Sugiyono (2010, p. 407) development research is a type of research that aims 
to create certain works, test the validity, efficiency and efficiency of the work. The media developed in this study used a 4-D model consisting of 4 stages, namely define, design, develop and dessiminate.

The population in this study was carried out on the fifth grade students of Surabaya UJUNG IX SDN, which consisted of 134 VA students, VB, VC, and VD. While the random sample chosen came from the VB class which amounted to 33 people, with a total of 15 male students and 18 female students.

The VB class was chosen as the research sample as the implementation class and the VD class was chosen as the trial class based on the results of the initial study, namely the Social Studies learning outcomes data in $3.1 \mathrm{KD}$ KD 4.1 showed lower values compared to VA and VC classes.

Research on the development of Pop Up 3D general map learning media was carried out at UJUNG IX SDN located on Jl. Sawahpulo No. 1, Semampir District, Surabaya. In April 2019.

Based on the design and design of the research, the development research procedures are as follows: 1) Define stage (defining), the objective at this stage is to determine and provide definitions of learning needs by analyzing the purpose and scope of the material. description of activities at this stage include: initial-end analysis, student analysis, concept analysis, material analysis and assignments, formulation / specification of learning objectives. 2) Stage design, the drafting phase of the learning media includes the following steps: test preparation, media development, format selection, initial design of learning media. 3) Stage develop, the development stage serves to produce the second draft text that has been improved based on expert advice and the data obtained from the experiment dealing with learning media includes the following activities: a) Appraisal of experts learning, the media that have been designed in draft I will be evaluated or verified by a team of experts, the verifiers are people who have competence in the field of social studies subjects and interested parties with the preparation of a general map of 3D Pop Up, as well as parties who can provide constructive criticism and suggestions in compiling learning media. The criticism and explanation will later be taken into consideration to improve draft I which then continues to draft II. The following are the validated components including: content validation, display validation, language validation, practical validation and validation of efficiency and effectiveness. b) Limited trial, the implementation of learning media trials was carried out after producing draft II on the research subject. The Observer was asked to write down all the actions obtained from the activities and responses of the students. These results will be useful as material for improving learning media in this study. Limited testing was conducted on social studies subjects regarding the geographic characteristics of students of SDN UJUNG IX in VD class, Surabaya. This media trial design uses one group pre-test post-test design in the following table:
Table 2.1, One Group Pre-test Post-test Design

\begin{tabular}{|c|c|c|c|}
\hline Class & Pretest & Treatment & Postest \\
\hline Trial & $\mathrm{T} 1$ & $\mathrm{X}$ & $\mathrm{T} 2$ \\
\hline
\end{tabular}

Information:

T1: Initial test to see student mastery before learning takes place, used to test the sensitivity of the test item.

T2: Final test to see the mastery of students after learning take place.

$\mathrm{X}$ : Treatment in the trial class

$\mathrm{T} 1=\mathrm{T} 2$

Research design at the development stage uses a trial design with one data collection. This design is described as follows:

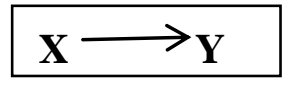

X: Treatment, namely social studies learning with a general map of 3D Pop Up through the Discovery Learning learning model in the sub-topics of Indonesia's geographical characteristics.

Y: The results of the observation after the treatment was done, namely describing the activities of the students, the implementation of the lesson plan using the Discovery learning model with the 3D Pop Up general map media (educator activities), the value of creativity, and student learning outcomes (attitudes, skills and knowledge).

Zainal (2009, p.129)

Data collected from the media development comes from the development procedure data using a $4 \mathrm{D}$ model that includes the stages of defining (designing), the design stage (design), the stage of development (develop), and the stage of distribution (desseminate). In addition to these data, there are also media validation data and learning tools derived from expert evaluations in the form of validation sheets.

The collected data comes from the student response questionnaire and evaluation of the questionnaire responses by educators to this learning media. In the questionnaire response to the media used there are 4 alternative answers for each item statement, namely very good, good, sufficient, and lacking. Measurements in the questionnaire response to the media of this study using scoring rules. The data collected comes from data on the value of creativity and learning outcomes of students which includes the realm of knowledge, attitudes, and skills.

This study uses a validation sheet for the development of media and learning devices by validators, media validation sheets derived from student and teacher response questionnaires to the media, validation sheets for media use effectiveness obtained from student creativity assessment sheets and student learning outcomes assessment sheets. 
Data from the validation by experts were identified by considering the results of evaluations, criticisms and expert suggestions regarding learning devices. The validated devices included RPP, LKPD, THB knowledge, observation sheets, teaching materials, 3D Pop Up general map media, media response questionnaires, and grades creativity. Validation analysis of learning devices using validity test. According to Sugiyono (2014, p.121), the instrument is said to be valid if the tool to obtain data is also valid. If it is valid, the instrument is ready to be used to measure all things that can be measured. The validity test in this study uses component identification by checking scores per item with the final score derived from the total score of each item. If there are components that do not meet the requirements, then the component needs to be examined more deeply. Sugiyono (2012, p. 124), said there are two conditions that need to be fulfilled, namely:

1) If $\geq 0,3$, then the question item from the questionnaire is declared valid

2) If $\leq 0.3$, then the question item from the questionnaire is invalid. The correlation formula based on Pearson Product Moment according to Sugiyono (2014: 183) is as follows:

The correlation coefficient interpretation is based on a guideline table on the validity of learning devices.

Table 2.2 Guidelines for Providing Validity Interpretations

\begin{tabular}{|l|l|}
\hline Relationship Level & Coefficient Interval \\
\hline $0,0-0,25$ & Less Valid \\
\hline $0,26-0,50$ & Valid enough \\
\hline $0,51-0,75$ & Reliable \\
\hline $0,76-1,00$ & Very Valid \\
\hline
\end{tabular}

Learning devices are said to be good, if each device is in the "valid" category, or "very valid". Sugiyono (2014: 121) said that the reliability test carried out repeatedly on the same object, will get the same data. In this study the reliability of each instrument used the cronbach 'alpha (a) coefficient with the help of SPSS. The instrument is reliable if the value of cronbach 'alpha (a) is greater than 0.6. According to Saifuddin Azwar (2007: 78) the formula used is as follows:

Table 2.3, Guidelines for Providing Interpretation of Reliability

\begin{tabular}{|l|l|}
\hline Relationship Level & Coefficient Interval \\
\hline $0,0-0,25$ & Less Valid \\
\hline $0,26-0,50$ & Valid enough \\
\hline $0,51-0,75$ & Reliable \\
\hline $0,76-1,00$ & Very Valid \\
\hline
\end{tabular}

This study uses descriptive quantitative data analysis techniques with percentage techniques.

Percentage of learning creativity

$=\frac{\text { the number of each scores for each subject score }}{\text { maximum score }} \times 100 \%$

Finding the average learning creativity of students with the formula:

$$
\mathrm{x}=\frac{\text { the percentage of the creativity value students }}{\text { number of students }}
$$

Arikunto (2006, p.282) argues that quantitative data in the form of numerical processing results are obtained in a total way and compared with the desired amount to get a percentage result. Determination of values is categorized according to Hadi in Arikunto, (2011, p. 250) are: very high (81\% - 100\%), high (61\% - 80\%), sufficient (41\% - 60\%), low $(21 \%-40 \%)$, very low $(<21 \%)$. This technique is often called quantitative descriptive analysis with percentage techniques.

\section{RESULT AND DISCUSSION}

The feasibility of the 3D Pop Up general map media can be seen from the results of the questionnaire responses of educators and students to the media in the trial class (class VB SDN UJUNG IX / 34). Based on the results of filling in the educator's response questionnaire to the media, the average score was $88.33 \%$ with the positive response category. Based on the results of filling in the questionnaire responses of students to the media it is known that the average value of the percentage of responses from 24 students is in the range of $80-90 \%$, while 9 students are in the range of $91-100 \%$. so that it can be concluded that the response of students to the media is positive. The results of this study are also supported by research conducted by Sholikhah (2017) which states that:

"The results of a large group trial based on student responses to the Pop Up Book learning media are positive, with an average percentage of $96.9 \%$. While the results of teacher questionnaire responses in large groups, the results obtained that the percentage of each indicator is more than $65 \%$ with a positive category.

In addition to filling out the questionnaire, the feasibility study was also measured by observing the activities of the pilot and implementation classes in the IPS learning activities using the 3D Pop Up general map media. Data on student activities during learning in the trial class and implementation class are presented in the following table.

Table 3.1, Observation Results of Student Activities in the Trial Class

\begin{tabular}{lcll}
\hline Observed Aspects & \multicolumn{3}{l}{$\begin{array}{l}\text { Percentage of student activity } \\
\text { Meeting Average }\end{array}$} \\
& $\begin{array}{l}\text { Ideal Range } \\
\text { (\%) }\end{array}$ \\
\hline Listen to the educator's explanation of the 9,52 & $10,7110,12$ & $9 \% \leq \mathrm{P} \leq 11 \%$ \\
purpose of learning & & \\
Understanding contextual issues in the LKPD & $28,5727,3827,98$ & $27 \% \leq \mathrm{P} \leq 33 \%$ \\
Resolve contextual problems & $29,7628,5729,17$ & $27 \% \leq \mathrm{P} \leq 33 \%$ \\
Discuss / ask friends / Educators & $20,2420,2420,24$ & $18 \% \leq \mathrm{P} \leq 22 \%$ \\
Make Conclusion & $10,7110,7110,71$ & $9 \% \leq \mathrm{P} \leq 11 \%$ \\
Behavior that isn't relevant & $1,192,38$ & 2,38 & $0 \% \leq \mathrm{P} \leq 5 \%$ \\
\hline
\end{tabular}


Table 3.2, Observation Results of Student Activities in the Trial Class

\begin{tabular}{llll}
\hline \multirow{2}{*}{ Observed Aspects } & \multicolumn{4}{l}{ Percentage of student activity } \\
& Meeting & Average & Ideal Range \\
& 1 & 2 &
\end{tabular}

Listen to the educator's explanation of the $9,52 \quad 9,52 \quad 9,52 \quad 9 \% \leq \mathrm{P} \leq 11 \%$ purpose of learning

Understanding contextual issues in the $27,3828,5727,98 \quad 27 \% \leq P \leq 33 \%$ LKPD

Resolve contextual problems

Discuss / ask friends / Educators

$30,9530,9530,95 \quad 27 \% \leq P \leq 33 \%$

Make Conclusion

$19,0519,05 \quad 19,05 \quad 18 \% \leq P \leq 22 \%$

Behavior that isn't relevant $10,71 \quad 9,52 \quad 10,12 \quad 9 \% \leq P \leq 11 \%$

Behavior that isn't relevant $2,38 \quad 2,38 \quad 2,38 \quad 0 \% \leq P \leq 5 \%$

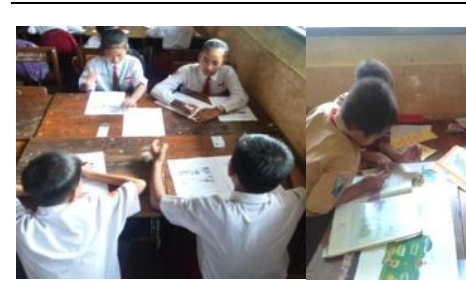

In the table, it

$2,38 \quad 2,38 \quad 2,38 \quad 0 \% \leq P \leq 5 \%$
all aspects of student activities at meeting 1 and meeting 2 reach tolerance, because they are within the ideal time span. This means that the activities of students meet good criteria. The following figure shows the activities of students during learning.

$\begin{array}{ccc}\text { Discuss } & \text { Finishing LKPD with } & \begin{array}{c}\text { Presentation about } \\ \text { media peta umum 3D }\end{array} \\ \text { activities with } & \text { group class } & \text { Pop Up }\end{array}$

This situation is in accordance with the opinion of Kumar Shah (2016, p.84) which states that elementary school students like to study social studies with cooperative learning, field trips, working in groups and actively, thinking critically, conducting group discussions, using question and answer techniques and presentation

The effectiveness of learning media is measured using a sheet of observation of the value of creativity. The researcher first compared the value of creativity of students both in the pilot class and the implementation class with the data on the creativity value of IPS material in KD 3.1 in semester 1. Based on these data, the average percentage value of the creativity of the pilot class was $61 \%$ and the implementation class was $64 \%$. So that it can be concluded that IPS learning creativity in general is in the sufficient category.

When carrying out learning activities using the 3D Pop Up general map media as many as two meetings, students are observed by observers and the observer's assessment of the value of creativity both products and processes is written on the creativity assessment sheet which includes aspects of giving ideas, solving problems, accuracy of information and product display. The results of the observations are presented in the following table:

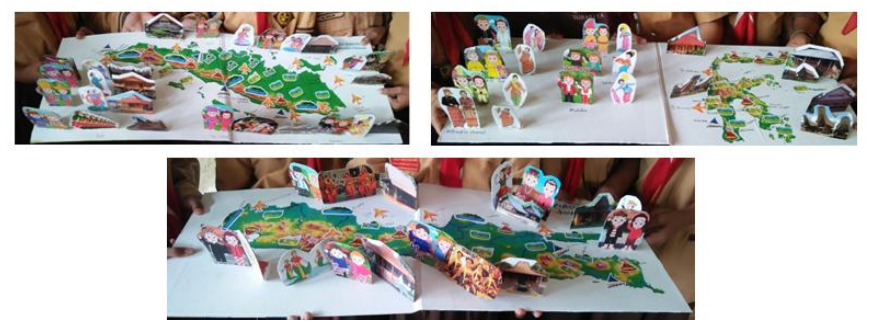

\begin{tabular}{|l|l|l|l|}
\hline \multicolumn{2}{|l|}{ Creativity Value of Trial Class } & \multicolumn{2}{|c|}{ Creativity Value of Implementation Class } \\
\hline Before use media & $\begin{array}{l}\text { After use } \\
\text { media }\end{array}$ & Before use media & After use media \\
\hline $61 \%$ & $80,11 \%$ & $64 \%$ & $84,84 \%$ \\
\hline
\end{tabular}

The results showed that the average percentage of the creativity value of the experimental class after using the 3D Pop Up general map media increased to $80.11 \%$ and $84.84 \%$ in the implementation class. So that it can be concluded that the value of the creativity of social studies learning of students in VB and VD classes after learning to use the 3D Pop Up general map media is in the high category. The following figure shows the creativity of students after making general map 3D Pop Up. In addition to the value of creativity, the effectiveness of learning media is also measured using learning outcomes that include knowledge, attitudes and skills. In the realm of knowledge, a comparison is used in the form of questions about pre test and post test. The following is the data on the average score of the learning outcomes in both the trial and implementation classes.

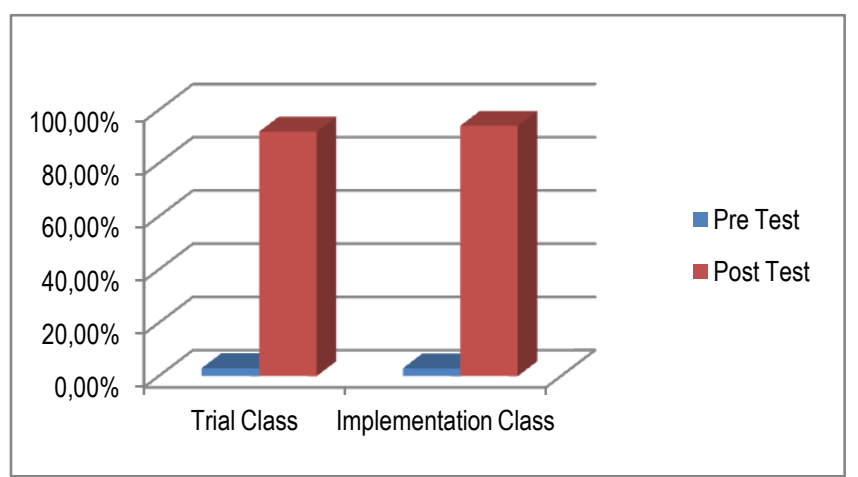

Diagram 3.1, Classical Completion of Pre Test and Post Test

Based on the diagram above shows the value of the classical pre-test completeness in the trial class is 3.03\% and in the implementation class $2.94 \%$. This shows that students' initial knowledge in this material is in the "less" category. While the value of classical completeness post test in the trial class was $91.93 \%$ and in the implementation class $94.12 \%$. This shows that students' knowledge after learning using the 3D Pop Up general map media has increased and is in the "very high" category.

On the aspects of skills and attitudes of students showed a significant increase, as evidenced by the acquisition of the results of classical skills observations in the trial class of $91.43 \%$ and $88.24 \%$ in the implementation class. Whereas the attitudinal aspect of the results of observations in the trial class was $81.43 \%$ and in the implementation class was $82 \%$. The percentage is in the 
very good category.

Based on these data, the 3D Pop Up general map media is said to be effectively used as an alternative to elementary school social studies learning class V. This is in line with the opinion of Hobri (2010, P.28), that effective learning can be created within students actively involved in organizing and discovery of information (knowledge), students are not only passive in receiving the knowledge conveyed by educators but they can actively respond.

\section{CONCLUSION}

Based on data analysis and discussion of research results, conclusions are obtained as follows:

1. This development research generates a 3D Pop Up general map media with Discovery Learning models along with learning devices that can increase the value of creativity and social studies learning outcomes in the material of Indonesia's geographical characteristics in grade $\mathrm{V}$ elementary school. The development of the 3D Pop Up general map media is through the validation and field trials stages according to the 4-D development research model. The validation results by the validators include:

a. the development of learning media gets a good category with an average score of 3.65 ;

b. the development of the learning implementation plan has a good category with an average score of 3.6;

c. teaching materials developed have good categories with an average score of 3.3 ;

d. the activity sheet of students developed has a good category with an average score of 3.6;

e. the learning outcomes test developed has a good category with an average score of 3.1 ;

f. the observation sheet developed has a good category with an average score of 3.1 ;

g. the questionnaire responses of educators and students to the media developed have very good categories with an average score of 3.8 ;

h. the value of creativity of students gets a very good category with an average score of 3.8 .

2. The feasibility of $3 \mathrm{D}$ Pop Up general map media developed after going through the stages of validation and field trials can be seen from the responses of students and educators to the media developed to obtain an average percentage of more than $80 \%$ with the category of positive responses (worthy).

3. The general 3D Pop Up media map is effective in increasing the value of creativity and learning outcomes of social studies material in Indonesia's geographical characteristics in grade $\mathrm{V}$ elementary school. This can be seen from:

a. The completeness of the learning outcomes of students in social studies subject matter of geographic characteristics of Indonesia in a classical manner is achieved, this can be seen from the learning outcomes of students in the implementation class $94.12 \%$ reaching a value of $\geq 75$, affective learning outcomes $82 \%$ achieving good criteria, and psychomotor learning $88.24 \%$ achieved good criteria. These learning outcomes show a significant increase when compared to the initial data of observation.

b. The activities of students during social studies learning using the 3D Pop Up general map media meet the good criteria because they are within the ideal time span.

c. The value of creativity of students after using the 3D Pop Up general map media in social studies learning increased in the high category with an average percentage of $84.84 \%$.

\section{REFERENCES}

Aeni, Nur. 2017. Pengembangan Media Pop Up Book dalam Pendidikan Nilai Nasionalisme Materi Peristiwa Sekitar Proklamasi untuk Meningkatkan Berpikir Kritis Siswa Kelas V SD. Surabaya: UNESA

Aqib, Zainal. 2013. Model-model, Media, dan Strategi Pembelajaran Kontekstual (Inovatif). Bandung: Yrama Widya.

Arifin, Zainal. 2009. Evaluasi Pembelajaran. PT. Remaja Rosdakarya: Bandung

Arikunto, Suharsimi. 2006. Prosedur Penelitian, Suatu Pendekatan Praktik. Jakarta: Rineka Cipta.

Arsyad, Azhar. 2011. Media Pembelajaran. Jakarta: PT Raja Grafindo Persada.

Asyhar, Rayanda. 2011. Kreatif Mengembangkan Media Pembelajaran. Jakarta: Gaung Persada (GP) Press.

Budiningsih, Asri. 2005. Belajar dan Pembelajaran. Jakarta: PT Rineka Cipta

Hobri. 2010. Metodologi Penelitian Pengembangan (Aplikasi pada Penelitian Pendidikan Matematika). Jember : Pena Salsabila

Lampiran permendikbud No. 104 tahun 2014

Peraturan Presiden Nomor 87 Tahun 2017

Piaget, Jean, \& Barbel Inhelder, 2010.Psikologi Anak, Terj. Miftahul Jannah, Yogyakarta : Pustaka Pelajar.

Riyanto, Yatim. 2007. Metodologi Penelitian Pendidikan Kualitatif dan Kuantitatif. Surabaya: Unesa University Press

Rubin, E.G.K. (2015). Pop -up and Movable Books in The Context of History. Retrieved from http://popuplady.com/about01 - history.shtml

Shah, Kumar. (2016). Cooperative Learning: Review of Research and Practice. Australian Journal of Teacher Education, 41(3).

Sholikhah. 2017. Pengembangan Media Pop Up Book Untuk Meningkatkan Kemampuan Menulis Kreatif Pada Mata Pelajaran Bahasa Indonesia Materi Menulis Karangan Kelas V Sdn Rowoharjo Tahun Ajaran 2016/2017. Universitas Nusantara PGRI Kediri: Kediri

Sugiyono. 2011. Metode Penelitian Kuantitatif, Kualitatif dan R\&D. Bandung: Afabeta

Sugiyono. 2011. Dasar-Dasar Penelitian IImiah. Bandung: Pustaka Setia

Suyono dan Hariyanto, 2011. Belajar dan Pembelajaran. Bandung: PT Remaja Rosdakarya Offset.

Tilaar, H.A.R. 2012. Perubahan Sosial dan Pendidikan. Jakarta: Rineka Cipta 